Praxis : Jurnal Sains, Teknologi, Masyarakat dan Jejaring | Vol. 3 | No. 2 | Maret 2021

\title{
Inovasi Dan Kreativitas Kang Bagong Catering Semarang Di Tengah Pandemi
}

\author{
Widiyanti'; Vinsensia Retno Widi Wisayang ${ }^{2}$ \\ Fakultas Ekonomi Akuntansi Universitas Semarang ${ }^{1}$ \\ Universitas Katolik Soegijapranata ${ }^{2}$ \\ email: widiyanti@usm.ac.id
}

\begin{abstract}
Abstrak
Pandemi covid-19 telah melumpuhkan sendi-sendi perekonomian, banyak sektor usaha yang mengalami dampak langsung dari krisis ekonomi yang berbeda ini. Pengusaha dituntut untuk bisa kreatif dan mampu berinovasi terhadap produk, kemasan, maupun cara pemasarannya dimasa pandemi covid-19 ini untuk dapat bertahan dan mampu beradaptasi dengan perubahan. Inovasi yang dilakukan Kang Bagong Catering ditengah situasi pandemi yang terjadi antara lain adalah berkreatifitas untuk varian produk dan kemasan/packing, layanan ready to eat, pesan antar, take away, melayani partai kecil bahkan eceran, semua dilakukan agar karyawan tetap ada kegiatan, dan tetap terjalin interaksi dan komunikasi baik dengan para customer terutama para pelanggan setianya. Diantara kreatifitas dalam kemasan/packing adalah penggunakan mika box untuk membuat kemasan menjadi lebih cantik dan menarik, penggunaan besek, rantang bambu, ceting bambu, dan sokase (box atau wadah serbaguna yang terbuat dari anyaman bambu) yang ramah lingkungan dan juga dapat digunakan kembali untuk keperluan lain sehingga pelanggan mendapatkan nilai lebih. Pengembangan usaha yang dilakukan Kang Bagong Catering antara lain adalah menawarkan berbagai variasi, inovasi dan kreativitas baik dalam varian, ukuran, bentuk, jenis, maupun kemasan/packing sehingga pelanggan atau konsumen mempunyai banyak alternatif pilihan. Meningkatkan strategi pemasaran dan memanfaatkan peluang potensial untuk dikembangkan, promosi dilakukan melalui berbagai sarana media dan juga melalui sosial media seperti face book, twitter, dan status whatsapp (WA) yang saat ini sedang in digunakan dan diminati oleh masyarakat sehingga dengan mudah banyak pihak terinformasi dengan berbagai produk yang ditawarkan. Metode penelitian yang digunakan dengan menggunakan metode kualitatif dengan pendekatan fenomenologi. Informan penelitian yang digunakan yaitu Pemilik dan manajemen Kang Bagong Catering Semarang sebagai objek penelitian. Pengumpulan data dilakukan pada observasi (participant observation), wawancara mendalam (indepth interview) dan dokumentasi. Analisis data yaitu data reduction, data display dan conclusion drawing/verification. Uji kredibilitas data dengan triangulasi dan member check.
\end{abstract}

Kata Kunci : Inovasi, Kreatifitas, Pengembangan Usaha.

\begin{abstract}
The covid-19 pandemic has paralyzed the joints of the economy, many business sectors have experienced the direct impact of this different economic crisis. Entrepreneurs are required to be creative and able to innovate in their products, packaging, and marketing methods during the Covid-19 pandemic in order to survive and be able to adapt to changes.Kang Bagong Catering's innovations in the midst of a pandemic situation include creativity in product variants and packaging, ready to eat services, delivery orders, take away, serving small parties and even retail, all done so that employees continue to have activities and remain There is good interaction and communication with customers, especially loyal customers. Among the creativity in packaging is the use of mica boxes to make the packaging more
\end{abstract}


beautiful and attractive, the use of baskets, bamboo baskets, bamboo ceting, and sokase (multipurpose boxes made of woven bamboo) which are environmentally friendly and can also be reused for other needs so that customers get more value. Kang Bagong Catering business development includes offering various variations, innovations and creativity both in variants, sizes, shapes, types, and packaging so that customers or consumers have many alternative choices. Improving marketing strategies and taking advantage of potential opportunities to be developed, promotions are carried out through various media facilities and also through social media such as face books, twitter, and whatsapp status (WA) which are currently being used and in demand by the community so that many parties are easily informed by variety of products offered.The research method used is a qualitative method with a phenomenological approach. The research informants used were the owner and management of Kang Bagong Catering Semarang as the research object. Data collection was carried out on observation (participant observation), in-depth interview (in-depth interview) and documentation. Data analysis, namely data reduction, display data and conclusion drawing / verification. Test data credibility by triangulation and member check.

Keywords: Innovation, Creativity, Business Development.

\section{PENDAHULUAN}

Situasi pandemi yang berdampak pada semua sektor kehidupan masyarakat dan perekonomian berbeda dengan krisis-krisis sebelumnya, tidak terkecuali para pebisnis dan pengusaha, khususnya usaha catering yang hampir zero income atau tidak ada pemasukan sama sekali selama pandemi covid-19 ini berlangsung. Diberlakukannya social distancing dan physical distancing dalam rangka antisipasi penyebaran pandemi covid-19 yang masih berlangsung ini seolah-olah menutup aspek revenue untuk usaha catering yang melibatkan banyak orang berkumpul dalam suatu acara.

Pebisnis dan pengusaha dituntut beradaptasi dengan perubahan, bagaimana memutar otak dengan cara berkreativitas dan berinovasi terhadap produk maupun cara pemasarannya untuk bisa tetap bertahan ditengah krisis yang terus menghantam. Diharapkan kreativitas dan inovasi yang tercipta akan sanggub memunculkan peluang usaha yang memberikan angin segar ditengah sesaknya perekonomian yang terjadi.
Kinerja perusahaan dan kemampuan untuk bertahan dalam persaingan ditentukan oleh kecepatan sebuah perusahaan mengembangkan kompetensi berbasis pengetahuan. Dengan pengetahuan, sebuah perusahaan dapat tetap mempertahankan keunggulan bersaingnya dan meningkatkan kinerja perusahaannya untuk belajar lebih cepat daripada pesaingnya (Daud dan Yusoff, 2010).

Kang Bagong Catering adalah perusahaan yang bergerak dibidang usaha jasa boga (Catering), dirintis sejak tahun 1999 oleh Ibu $\mathrm{Hj}$. Kanti Haryati. Kang Bagong Catering beralamat di Jl.Sriwidodo Utara No.105 Semarang. Kang Bagong Catering menyediakan berbagai pilihan, baik untuk corporate event, pernikahan, khitanan, rapat maupun lainnya sesuai kebutuhan pelanggan dan siap menjadikan setiap event senantiasa spesial. Dengan visi menjadi pemimpin dalam jasa layanan catering siap memberikan layanan terbaik, menu masakan yang kreatif, dengan gaya dan sajian yang berbeda serta harga yang kompetitif, menjadikan kepuasan pelanggan sebagai prioritas utama dan berkembang bersama kepercayaan para pelanggan yang terjaga dalam jangka panjang. 
Ditengah situasi pandemi yang terjadi dimana tidak ada event besar sama sekali mau tidak mau harus berfikir keras dan cerdas bagaimana cara agar usaha tetap berjalan, sehingga dilakukan berbagai inovasi mulai dari kreatifitas untuk varian produk dan kemasan/packing, layanan ready to eat, pesan antar, melayani partai kecil bahkan eceran, serta take away semua dilakukan agar karyawan tetap ada kegiatan, tetap terjalin interaksi dan komunikasi baik dengan para customer terutama para pelanggan setia sehingga tetap ada revenue. Pada dasarnya melakukan inovasi merupakan kemampuan mendayagunakan pikiran dan sumber daya yang ada untuk menghasilkan karya dengan sentuhan kreatifitas.

Inovasi dapat diartikan sebagai proses dan/atau hasil pengembangan pemanfaatan/mobilisasi pengetahuan,

keterampilan (termasuk keterampilan teknologis) dan pengalaman untuk menciptakan atau memperbaiki produk (barang dan/atau jasa), proses, dan/atau sistem yang baru, yang memberikan nilai yang berarti atau secara signifikan (terutama ekonomi dan sosial). Reka baru sebagai suatu objek juga memiliki arti sebagai suatu produk atau praktik baru yang tersedia bagi aplikasi, umumnya dalam suatu konteks komersial. Biasanya, beragam tingkat kebaruannya dapat dibedakan, bergantung pada konteksnya: suatu inovasi dapat bersifat baru bagi suatu perusahaan, baru bagi pasar, atau negara atau daerah, atau baru secara sejagat. Sementara itu, reka baru sebagai suatu kegiatan merupakan proses penciptaan reka baru, sering kali diidentifikasi dengan komersialisasi suatu reka cipta. https://id.wikipedia.org/wiki/Reka_baru (diakses, 14.08.2020)

Kreatifitas merupakan kemampuan yang dimiliki seseorang untuk menemukan dan menciptakan suatu hal, cara-cara baru, model baru, yang berguna bagi diriya dan masyarakat. Hal baru adalah sesuatu yang bersifat inovatif. Kreatifitas memegang peranan penting dalam kehidupan dan perkembangan dunia usaha. https://sites.google.com/a/mhs/.uinjkt.ac.id /rezafathurahman/kreativitas

(diakses.15.08.2020)

Kreatif dan inovatif sangatlah penting dan diperlukan dalam kehidupan sehari-hari, karena sangat menentukan kualitas hidup dan kualitas usaha/bisnis yang kita geluti apalagi ditengah pandemi covid-19 yang masih berlangsung ini, sehingga hal ini membuat penulis tertarik untuk melalukan penelitian tentang peran inovasi dan kreativitas ditengah pandemi. Sebelumnya penelitian serupa pernah dilakukan oleh Siti Nurjanah (2015) yang berjudul "Peranan Manajemen Inovasi Dalam meningkatkan Kinerja Organisasi Pendidikan". Penelitian ini menggunakan desain penelitian deskriptif yang bertujuan untuk mendeskripsikan peranan manajemen inovasi dalam menghadapi persaingan global sehingga organisasi pendidikan akan memiliki keunggulan kompetitif. Terobosan inovasi yang bisa dilakukan pada organisasi jasa adalah dengan menciptakan model bisnis baru, mengembangkan layanan baru, membuat interface pelanggan baru, membuat inovasi administrasi, inovasi terealisasi apabila didukung oleh kreatifitas, pengetahuan, kompetensi, kebutuhan masyarakat.

Penelitian Dani Danuar Tri (2013) yang berjudul "Pengembangan Usaha Mikro Kecil dan Menengah (UMKM) Berbasis Ekonomi Kreatif di Kota Semarang". UMKM kreatif belum mampu memberikan predikat khusus bagi Kota Semarang karena mereka memiliki kemampuan yang terbatas serta mengalami permasalahan dalam pengembangan usahanya. Beberapa permasalahan yang dihadapi UMKM kreatif kota semarang antara lain permasalahan permodalan yang terbatas, bahan baku dan penggunaan peralatan produksi yang sederhana, media pemasaran yang terbatas karena belum adanya sentra 
UKMM, biaya transaksi yag cukup banyak, tenaga kerja yang kurang terampil, dan masalah pendaftaran hak cipta. Solusi dari pihak pemerintah untuk kemajuan UMKM kreatif dikota semarang yaitu dengan dilakukan antisipasi ke depan yang sifatnya kontinyu.

Penelitian Siti Ngainnur Rohmah (2020 yang berjudul "Adakah Peluang Bisnis di Tengah Kelesuan Perekonomian Akibat Pandemi Coronavirus Covid-19?" Pandemi corona telah melumpuhkan sendi-sendi perekonomian. Perusahaan Negara banyak yang mengalami kerugian. Sektor usaha swasta pun berangsur runtuh. Masyarakat menjerit karena banyak yang tidak bisa bekerja mencari nafkah, sementara itu kebutuhan hidup tetap menuntut. Penelitian ini memaparkan bagaimana mencari peluang usaha yang tepat ditengah kondisi Pembatasan Sosial Berskala Besar (PSBB) yang bertujuan untuk memutus mata rantai penyebaran virus Covid-19.

Penelitian Taufik (2020) yang berjudul "Dampak Pandemi Covid-19 Terhadap Bisnis dan Eksistensi Platform Online" Penelitian ini bertujuan menemukenali dan menganalisis dampak pandemic Covid-19 terhadap kegiatan Bisnis berbasis platform online di Jakarta. Metode penelitian yang digunakan adalah metode kualitatif deskriptif, menggunakan sumber data sekunder dari hasil riset, referensi dan pemberitaan online yang terkait dengan penelitian. Teknik pengumpulan data menggunakan teknik dokumentasi. Ditemukan bahwa dampak pandemic Covid-19, terkluster pada 3 keaadaan aktivitas bisnis, pertama bisnis bertahan atau stabil, kedua bisnis yang menurun dan ketiga bisnis berkembang. Bisnis yang stabil melalui penyesuaian model interaksi menggunakan platform aplikasi online adalah pendidikan, terutama untuk hantaran makan/minuman dan kebutuhan pokok, dan produk kesehatan. Bisnis yang menurun adalah yang berbasis kunjungan atau keberadaan konsumen di tempat sangat terdampak dari pandemi Covid-19, seperti angkutan umum, pariwisata, perhotelan, ritel offline, pusat perbelanjaan, angkutan orang dan barang. Bisnis yang berkembang karena dinamika pasar dan penyesuaian interaksi menggunakan platform aplikasi online seperti bisnis telekomunikasi, belanja online (kebutuhan pokok dan produk kesehatan), farmasi, produk kesehatan, termasuk usaha mikro kecil menengah (UMKM) yang beralih secara inovatif memproduksi produk kesehatan yang dibutuhkan dimasa pandemi Covid-19.

Penelitian Nurul Istifadah dan Heru Tjaraka (2017) yang berjudul "Kreativitas dan Inovasi Pada Industri Kreatif Untuk Meningkatkan Daya Saing dan Kesinambungan Pertumbuhan Ekonomi" Penelitian ini dilakukan untuk menganalisis strategi peningkatan kreativitas dan inovasi dalam pengembangan industri kreatif di Indonesia. Alat analisis yang diguanakan adalah SWOT analysis. Hasil analisis menunjukkan bahwa strategi pengembangan ekonomi kreatif harus didasarkan pada pilar sumber daya manusia, industri, teknologi, institusi, dan keuangan. Yaitu berupa: penguatan kualitas sumber daya manusia, peningkatan dan penguatan basis ekonomi kreatif (ekonomi kerakyatan) yang memiliki keunggulan kompetitif, penciptaan iklim usaha yang kondusif bagi pengembangan ekonomi kreatif, penguatan dari aspek kelembagaan, serta meningkatkan akses kepada lembaga keuangan.

Masih sangat sedikit penelitian serupa dilakukan, tidak ada event besar diadakan, komunikasi dan interaksi dengan customer harus tetap dilakukan, karyawan harus tetap ada kegiatan, dan tidak dapat diprediksi pasti kapan berakhirnya situasi pandemi yang terjadi, sedangkan dampak dari pandemi ini kian hari kian terasa, biaya-biaya tetap dan biaya-biaya variael tetap berjalan seiring banyak keterbatasan 
yang dirasakan. Berdasarkan kondisi tersebut maka sekiranya layak dilakukan penelitian dengan mengkaji dan menganalisis "Inovasi dan Kreativitas Kang Bagong Catering Semarang di Tengah Pandemi”.

\section{METODE PENELITIAN Pendekatan Penelitian}

Moleong, Lexy J (2010) mensintesiskan penelitian kualitatif adalah penelitian yang bermaksud untuk memahami fenomena tentang apa yang dialami oleh subjek peneliti misalnya perilaku, persepsi, motivasi, tindakan dan lain-lain secara holistik, dengan cara deskripsi dalam bentuk kata-kata dan bahasa pada suatu konteks khusus yang alamiah dan dengan memanfaatkan berbagai metode alamiah. Desain penelitian yang digunakan adalah menggunakan metode kualitatif dengan pendekatan fenomenologi. Proses pelaksanaan penelitian ini berusaha menggali secara luas penyebab terjadinya fenomena dan kondisi permasalahan yang terjadi pada saat itu. Pada dasarnya penelitian ini bertujuan untuk mengetahui sejauh mana peran inovasi dan kreativitas dalam beradaptasi dengan perubahan dan kemampuan bertahan ditengah situasi sulit.

\section{Tempat Penelitian}

Tempat penelitian adalah di usaha jasa boga (catering) "Kang Bagong Catering Semarang" yang beralamat di Jl.Sriwidodo Utara No.105 Semarang. Untuk menciptakan nuansa yang berbeda karena penelitian dilakukan secara langsung dilapangan bekerjasama dengan unis bisnis yang ada di lingkungan masyarakat.

\section{Informan Penelitian}

Moleong (2010) mendeskripsikan subjek penelitian sebagai informan, yang artinya orang pada latar penelitian yang dimanfaatkan untuk memberikan informasi tentang situasi dan kondisi latar penelitian. Informan penelitian yang digunakan dalam kaitannya dengan inovasi dan kreativitas yang dilakukan Kang Bagong Catering Semarang ditengah pandemi.

\section{Sumber Data Penelitian}

Dalam penelitian ini sumber data menggunakan sampel purposif (purposive sample) yang memfokuskan pada informan-informan terpilih yang kaya dengan kasus untuk studi yang bersifat mendalam (Nana Syaodih, 2007). Data yang diperlukan untuk mengetahui bagaimana peran inovasi dan kreativitas ditengah pandemi, data yang dikumpulkan melalui wawancara, observasi, maupun studi dokumentasi sumber data adalah subjek dari mana data itu diperoleh.

\section{Instrumen Penelitian}

Instrumen yang digunakan dalam penelitian ini disusun berupa pedoman wawancara, pedoman observasi dan pedoman dokumentasi yang dijabarkan dari kisi-kisi penelitian pada kuesioner, hal ini karena pendekatan yang digunakan dalam penelitian ini adalah pendekatan kualitatif. Instrumen pendukung pada penelitian ini adalah alat perekam suara (MP3 player), kamera digital, serta alat tulis.

\section{Model Penelitian}

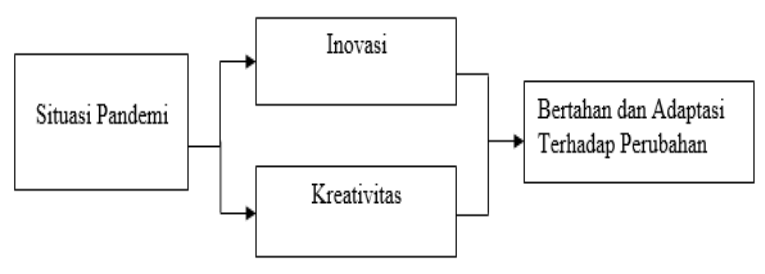

Gambar 4.6 Model Penelitian 


\section{Teknik Pengumpulan Data}

Sugiyono (2010) menyatakan pada penelitian kualitatif, pengumpulan data dilakukan pada natural setting dan teknik pengumpulan data lebih banyak pada observasi berperan serta, wawancara mendalam, dan dokumentasi. Mengacu pada pengertian tersebut, peneliti mengartikan teknik pengumpulan data sebagai suatu cara untuk memperoleh data melalui beberapa langkah atau tahapan, yaitu:

1. Wawancara (In Depht Interview) adalah pertemuan dua orang untuk bertukar informasi dan ide melalui tanya jawab, sehingga dapat dikonstruksikan makna dalam suatu topik tertentu (Esterberg dalam Sugiyono, 2009).

2. Observasi

(Observation) merupakan teknik pengumpulan data, dimana peneliti melakukan pengamatan secara langsung ke objek penelitian untuk melihat dari dekat kegiatan yang dilakukan.

3. Dokumentasi (Documentation) merupakan catatan peristiwa yang sudah berlalu. Dokumen bisa berbentuk tulisan, gambar, atau karya-karya monumental dari seorang. Studi dokumen merupakan pelengkap dari penggunaan metode observasi dan wawancara dalam penelitian kualitatif (Sugiyono, 2013).

Dalam Penelitian ini studi dokumen akan mendukung hasil dari wawancara dan observasi. Jadi ketiga teknik pengumpulan data ini akan saling melengkapi dan mendukung, oleh karena itu peneliti memakai teknik wawancara, observasi, dan studi dokumen dalam pengumpulan data.

\section{Teknik Analisa Data}

Sugiyono (2009) mengemukakan bahwa analisis data adalah proses mencari dan menyusun secara sistematis data yang diperoleh dari hasil wawancara, catatan lapangan, dan dokumentasi, dengan cara mengorganisasikan data kedalam kategori, menjabarkan kedalam unit-unit, melakukan sintesa, menyusun kedalam pola, memilih mana yang penting dan akan dipelajari, dan membuat kesimpulan sehingga mudah dipahami oleh diri sendiri mapun orang lain.

Adapun tahapan analisis data selama proses dilakukan bersamaan dengan pengumpulan data adalah sebagai berikut:

\section{Reduksi Data}

Reduksi data merupakan salah satu dari teknik analisis data kualitatif. Reduksi data adalah bentuk analisis yang menajamkan, menggolongkan, mengarahkan, membuang yang tidak perlu dan mengorganisasi data sedemikian rupa sehingga kesimpulan akhir dapat diambil. Reduksi tidak perlu diartikan sebagai kuantifikasi data.

\section{Penyajian Data}

Penyajian data merupakan salah satu dari teknik analisis data kualitatif. Penyajian data adalah kegiatan ketika sekumpulan informasi disusun, sehingga memberi kemungkinan akan adanya penarikan kesimpulan. Bentuk penyajian data kualitatif berupa teks naratif (berbentuk catatan lapangan), matriks, grafik, jaringan dan bagan.

\section{Penarikan Kesimpulan}

Penarikan kesimpulan merupakan salah satu dari teknik analisis data kualitatif. Penarikan kesimpulan adalah hasil analisis yang dapat digunakan untuk mengambil tindakan. 


\section{Teknik Keabsahan Data}

Terdapat beberapa teknik yang dapat digunakan untuk mengetahui keabsahan data, yaitu: 1) Teknik trianggulasi, 2) Pengecekan kebenaran informasi kepada para informan yang telah ditulis oleh peneliti dalam laporan penelitian (member check), 3) Akan mendiskusikan dan menyeminarkan dengan tema sejawat (peer debricfing), 4) Perpanjangan waktu penelitian. Cara ini akan ditempuh selain untuk memperoleh bukti yang lebih lengkap juga untuk memeriksa konsistensi tindakan para informan.

Ada tiga macam trianggulasi yang mencakup: 1) trianggulasi sumber yakni trianggulasi yang digunakan untuk menguji kredibilitas data dengan cara mengecek data yang telah diperoleh melalui beberapa sumber, 2) trianggulasi teknik atau metode pengumpulan data yang berasal dari wawancara, observasi, dan dokumen. 3) trianggulasi waktu pengumpulan data merupakan kapan dilaksanakannya trianggulasi atau metode pengumpulan data (Sugiyono, 2010). Berdasarkan uraian di atas penelitian ini menggunakan trianggulasi sumber data yang berupa observasi serta wawancara dengan narasumber secara langsung dan dokumen yang berisi catatan terkait dengan data yang diperlukan oleh peneliti dan melalui perpanjangan pengamatan.

\section{HASIL DAN PEMBAHASAN Inovasi Kang Bagong Catering}

Ancok (2012:34) mengatakan inovasi adalah proses menterjemahkan ide-ide ke dalam bentuk sebuah produk atau layanan yang dibeli orang atau sesuatu yang dihasilkan dari proses itu. Inovasi adalah kreativitas yang dapat diimplemantasikan dan memberi nilai tambah atas atas sumber daya yang kita miliki. Bayu (2006:4). Jadi untuk senantiasa dapat berinovasi memerlukan kecerdasan kreatif (Creative Intelligence).

Inovasi yang dilakukan Kang Bagong Catering Ditengah situasi pandemi yang terjadi antara lain adalah berkreatifitas untuk varian produk dan kemasan/packing, layanan ready to eat, pesan antar, take away, melayani partai kecil bahkan eceran, semua dilakukan agar karyawan tetap ada kegiatan, dan tetap terjalin interaksi dan komunikasi baik dengan para customer.

Varian Produk mulai dari ready to eat untuk sayuran dan lauk-pauk diantaranya cah sayuran, ayam bakar rica, tengkleng kambing, oseng lidah putren, pergedel kentang, sup iga bakar, ayam bakar kecap, dori cabe garam, tahu cabe garam, bakmie goring special, bakwan jagung udang, sup matahari, rawon, kakap tempura, tumis ati ampela, tempe goring, sup bayam jagung, tongkol cabe ijo, tumis taoge tempe, tahu cryspy, asem-asem daging sapi, sup iga kacang merah, bihun gorng special, ayam crispy sambal dabu, telur bumbu bali, oseng cumi, bakwan sayur udang, cap cay, ayam goring mentega, kakap telur asin, oseng sosis putren, sup rolade, kung pao chicken, udang tempura, asem-asem daging, trancam, pindang serani bandeng, oseng daun pepaya teri, sambal teri kacang, kakap asam manis, tumis soun jamur bakso, cah brokoli ala kungpao, ayam panggang BBQ, tongkol cabe ijo, ayam goreng lengkuas, cap cay Szechuan, oseng buncis wortel, rending jengkol, ayam bakar kemangi, sayur asem jawa, sayur lodeh, nila bakar/goreng, sapo telur puyuh, gule ayam daun papaya dan masih banyak varian berbagai variasi ready to eat lainnya yang terjadwal berbeda setiap harinya dengan harga terjangkau, serta melayani juga by reques dengan pemesanan $\mathrm{H}-1$.

Untuk varian makanan ringan, aneka puding, minuman dan makanan penutup diantaranya ada pie cocktail, pudding cup, siomay, lasagna, macaroni schootel, 
spaghetti bolognaise, poffertjes, kue ku, zuppa soup, pempek lenjer, pempek kapal selam, fruit cocktail salad, rujak potong, selada Bangkok, kebab, galantine sapi, galantine ayam, kering tempe kacang, kering kentang kacang, kembang goyang, ayam goreng kremes/bakar, pudding sedot, dan banyak lainnya selalu tersedia dapat dipesan setiap hari.

Tersedia juga berbagai makanan jenis frozen (dalam bentuk beku) antara lain galantine sapi frozen, galantine ayam frozen, kebab frozen dan es puter (klamud, coklat, kombinasi) dalam berbagai varian ukuran.

Varian lainnya adalah jajanan pasar diantaranya : dadar gulung, roll pisang keju, kroket, martabak lipat, mini macaroni schootel, risoles ragout, wajik, soes vla, tahu petis, kue kacamata, kurma siap makan dan jajanan lainnya serta tetap melayani pemesanan nasi box dengan berbagai varian, ukuran, dan harga sehingga pada konsumen bias memiliki banyak pilihan sesuai dengan selera dan kebutuhan.

Menjawab kebutuhan pasar dan minat konsumen tentang jamu tradisional yang dipercaya memiliki segudang manfaat kesehatan terutama untuk daya tahan tubuh ditengah kekewatiran akan situasi pandemi saat ini, Kang Bagong Catering menyediakan pula jamu tradisional khususnya beras kencur dan kunyit asam dalam kemasan praktis $250 \mathrm{ml}$ yang siap dinikmati.

\section{Kreativitas Kang Bagong Catering}

Menurut Hendro (2011:105) kegunaan pola pikir kreatif adalah menemukan gagasan, ide, peluang dan ispirasi baru, mengubah masalah atau kesulitan dan kegagalan menjadi sebuah pemikiran yang cemerlang untuk langkah selanjutnya, menemukan solusi inovatif, menemukan suatu kejadian yang belum pernah dialami atau yang pernah ada hingga menjadi sebuah penemuan baru, menemukan teknologi baru, mengubah keterbatasan yang ada sebelumnya menjadi kekuatan atau keunggulan.

Kang Bagong Catering melakukan banyak sekali kreativitas ditengah pandemi selain dalam inovasi produk dengan berbagai varian yang menggugah selera juga berkreativitas dalam kemasan/packing dan penyajian sehingga lebih praktis dan menarik. Beberapa kreatifitas dalam kemasan/packing adalah penggunakan mika box untuk membuat kemasan menjadi lebih cantik dan menarik terutama digunakan untuk mengemas aneka jenis pudding seperti pudding buah yang dengan sentuhan kreativitas menjadi berbagai bentuk bunga yang menarik dan menggugah selera makan dan sangat cocok untuk hantaran, seserahan ataupun sebagai hampers. Penggunaan besek, rantang bambu, ceting bambu, dan sokase (box atau wadah serbaguna yang terbuat dari anyaman bambu) yang ramah lingkungan dan juga dapat digunakan kembali untuk keperluan lain sehingga pelanggan mendapatkan nilai lebih.

Kreativitas dalam layanan juga dilakukan antara lain dengan melayani take away baik dalam kota maupun luar kota dengan kemasan yang aman, praktis dan menarik. Masih belum adanya event besar bukan berarti tidak ada ada event sama sekali belakangan mulai ada beberapa event dengan tetap memperhatikan dan mematuhi protokol kesehatan (jaga jarak, memakai masker sesuai standar dan melakukan cuci tangan dengan benar). Kang Bagong Catering memberikan layanan pandemi misal untuk acara pernikahan secara sederhana dengan model piring terbang atau sesuai reques dan kebutuhan pelanggan. 


\section{Pengembangan Usaha}

Konsep marketing atau yang lebih dikenal dengan pemasaran merupakan salah satu hal yang sangat penting dan tidak dapat diabaikan dalam menjalankan usaha catering. Berbicara pengembangan usaha maka sesungguhnya adalah membicarakan bagaimana strategi pemasaran produk agar laku terjual dan diminati pasar.

Pengembangan usaha yang dilakukan Kang Bagong Catering antara lain adalah menawarkan berbagai variasi, inovasi dan kreativitas baik dalam varian, ukuran, bentuk, jenis, maupun kemasan/packing sehingga pelanggan/konsumen mempunyai banyak pilihan menu. Selanjutnya adalah meningkatkan strategi pemasaran dan peluang potensial untuk dikembangkan, promosi dilakukan melalui berbagai sarana media dan juga melalui social media seperti face book, twitter, dan status whatsapp (WA) yang saat ini sedang in digunakan dan diminati oleh masyarakat sehingga dengan mudah banyak pihak terinformasi dengan berbagai produk yang ditawarkan.

Kemudahan melakukan pemesanan juga menjadi perhatian tersendiri, para konsumen bias memesan melalui whatsapp (WA) kenomer marketing yang tercantum, pemesanan dapat dilakukan $\mathrm{H}-1$ atau satu hari sebelumnya sebelum jam 15.00 Wib untuk menu selain yang ready everyday dan melakukan pembayaran melalui transfer sesuai dengan nominal pemesanan.

Dipenghujung tahun 2020 ini keadaan berangsur-angsur menunjukkan harapan, mulai ada beberapa event besar. Peraturan pemerintah setempat yang memberikan kebijakan dan izin mengadakan acaraacara tertentu seperti pesta pernikahan, khitanan, ulang tahun, syukuran, corporate event dan acara-acara lainnya dengan syarat mematuhi protokol kesehatan memberikan sedikit angin segar bahwa ini adalah awal move on kembali dari istirahat yang lumayan melelahkan. Kang Bagong Catering selalu siap membantu pelanggan dalam merencanakan dan mempersiapkan hidangan maupun suasana yang tidak akan terlupukan dengan memberikan layanan dengan cakupan area yang lebih besar, masakan yang kreatif, dengan gaya dan sajian yang berbeda serta harga yang kompetitif.

\section{PENUTUP Kesimpulan}

Berdasarkan hasil pembahasan yang telah diuraikan mengenai "Inovasi dan Kreativitas Kang Bagong Catering Semarang di Tengah Pandemi" dapat disimpulkan bahwa :

1. Inovasi yang dilakukan Kang Bagong Catering ditengah situasi pandemi yang terjadi antara lain adalah berkreatifitas untuk varian produk dan kemasan/packing, layanan ready to eat, pesan antar, take away, melayani partai kecil bahkan eceran, semua dilakukan agar karyawan tetap ada kegiatan, dan tetap terjalin interaksi dan komunikasi baik dengan para customer terutama para pelanggan setianya.

2. Kang Bagong Catering melakukan banyak sekali kreativitas ditengah pandemi selain dalam inovasi produk dengan berbagai varian yang menggugah selera juga berkreativitas dalam kemasan/packing dan penyajian sehingga lebih praktis dan menarik. Beberapa kreatifitas dalam kemasan/packing adalah penggunakan mika box untuk membuat kemasan menjadi lebih cantik dan menarik terutama digunakan untuk mengemas aneka jenis pudding seperti pudding buah 
yang dengan sentuhan kreativitas menjadi berbagai bentuk bunga yang menarik dan menggugah selera makan dan sangat cocok untuk hantaran, seserahan ataupun sebagai hampers. Penggunaan besek, rantang bambu, ceting bambu, dan sokase (box atau wadah serbaguna yang terbuat dari anyaman bambu) yang ramah lingkungan dan juga dapat digunakan kembali untuk keperluan lain sehingga pelanggan mendapatkan nilai lebih.

3. Pengembangan usaha yang dilakukan Kang Bagong Catering antara lain adalah menawarkan berbagai variasi, inovasi dan kreativitas baik dalam rasa, ukuran, bentuk, jenis, maupun kemasan/packing sehingga pelanggan/konsumen mempunyai banyak pilihan menu. Selanjutnya adalah meningkatkan strategi pemasaran dan peluang potensial untuk dikembangkan, promosi dilakukan melalui berbagai sarana media dan juga melalui social media seperti face book, twitter, dan status whatsapp (WA) yang saat ini sedang in digunakan dan diminati oleh masyarakat sehingga dengan mudah banyak pihak terinformasi dengan berbagai produk yang ditawarkan. Kemudahan melakukan pemesanan juga menjadi perhatian tersendiri, para konsumen bias memesan melalui whatsapp (WA) kenomer marketing yang tercantum, pemesanan dapat dilakukan $\mathrm{H}-1$ atau satu hari sebelumnya sebelum jam 15.00 Wib untuk menu selain yang ready everyday dan melakukan pembayaran melalui transfer sesuai dengan nominal pemesanan.

\section{Saran}

1. Sebaiknya selalu konsisten dengan pelayanan dan kualitas produk yang ditawarkan mengingat usaha catering adalah jenis usaha dengan persaingan tinggi sehingga menjaga para pelanggan setia mejadi hal yang sangat penting agar tercipta hubungan baik dan kerjasama yang to be continue.

2. Senantiasa beradaptasi dengan perubahan yang terjadi dan memanfaatkan setiap peluang usaha dengan inovasi dan kreatifitas yang terus-menerus update untuk menjawab tantangan dalam persaingan dan memenuhi kebutuhan customer, mengingat strategi yang digunakan bisa jadi digunakan pula oleh pesaing terdekat.

3. Situasi pandemi yang tidak dapat dipastikan kapan berakhirnya sebaiknya menjadi reminder tersendiri tentang pentingnya efektifitas dan efisiensi dalam semua kegiatan operasional, sehingga memberikan dukungan untuk tetap eksis ditengah keterbatasan karena masa pandemi yang masih berlangsung.

\section{DAFTAR PUSTAKA}

Ancook, Djamaludin, 2012, Psikologi Kepemimpinan dan Inovasi. Erlangga, Jakarta.

Dani Danuar Tri U.,Darwanto. 2013. Pengembangan Usaha Mikro Kecil dan Menengah (UMKM) Berbasis Ekonomi Kreatif di Kota Semarang. ISSN: 2337-3814, Vol.2, No.4.

Damanpour, Fariborz., Walker, Richard M., Avellaneda, Claudia N., (2009), Combinative Effects of Innovation Types and Organizational 
Praxis : Jurnal Sains, Teknologi, Masyarakat dan Jejaring | Vol. 3 | No. 2 | Maret 2021

Performance: A Longitudinal Study of Service Organizations. Journal of Management Studies 46:4.

Daud, S., \& Yusoff, W. F. W. (2011). How intellectual capital mediates the relationship between knowledge management processes and organizational performance? African Journal of Business Management, 5(7), 2607-2617. https://doi.org/10.5897/AJBM10.806

Hafsah, M.J. 2004, Upaya Pengembangan Usaha Kecil dan Menengah (UKM), Infokop Nomor 25 Tahun XX.

Hendro. (2011). Dasar-dasar Kewirausahaan. Jakarta: Erlangga.

Hurley, R. F. \& Hult, G. T. M. (1998). Innovation, Market Orientation and Organization Learning: An Intergation and Market Empirical Examination Journal of Marketing.

Istifadah, Nurul dan Heru Tjaraka. (2017). Kreativitas dan Inovasi Pada Industri Kreatif Untuk Meningkatkan Daya Saing dan Kesinambungan Pertumbuhan Ekonomi. Conference on Management and Behavioral Studies. ISSN:2541-3406

Kotler, P. \& Keller, K. L. (2012) Manajemen Pemasaran, (Edisi 14, Jilid 1) Jakarta: Erlangga.

Moleong L J. (2010). Metodologi Penelitian Kualitatif. Penerbit PT Remaja Rosdakarya Offset. Bandung.

Munandar, Utami. (2004) Pengembangan Emosi dan Kreativitas, Jakarta: Rineka Cipta.

Nana Syaodih. (2007). Metode Penelitian Pendidikan. Bandung: Rosda Karya.

Siti Nurjanah. 2015. Peranan Manajemen Inovasi Dalam Meningkatkan Kinerja Organisasi Pendidikan. ISSN: 23029791, Vol.2, No.1.

Siti Ngainnur Rohmah. 2020. Adakah Peluang Bisnis di Tengah Kelesuan Perekonomian Akibat Pandemi Coronavirus Covid-19?. ISSN: 22384638, Vol.4, No.1.

Sugiyono. (2009). Metode Penelitian Bisnis (Pendekatan Kuantitatif,
Kualitatif, dan R\&D). Bandung: Alfabeta.

Sugiono. (2010). Metodologi Penelitian Kualitatif \& RND. Bandung. Alfabeta. Sugiono. (2013). Metodologi Penelitian Kualitatif \& RND. Bandung. Alfabeta. Taufik, Eka Avianti Ayuningtyas. 2020. Dampak Pandemi Covid-19 Terhadap Bisnis dan Eksistensi Platform Online. Jurnal Pengembangan Wiraswasta. Vol.22, No.01.

Wijayanto, D, 2012. Pengantar Manajemen, Gramedia: Pustaka Utama.

https://www.medcom.id/ekonomi/entrepre neurship/GN14PYgN-kreatif-daninovatif-kunci-bertahan-di-masapandemi (diakses, 22.07.2020) https://id.wikipedia.org/wiki/Reka_baru (diakses, 14.08.2020)

https://sites.google.com/a/mhs/.uinjkt.ac.id /rezafathurahman/kreativitas (diakses.15.08.2020)

https://id.wikipedia.org/wiki/Pandemi(diak ses, 19.08.2020).

http://bbs.binus.ac.id/gbm/2017/07/07/teori -yang-biasa-digunakan-untukmengukur-perilaku-konsumen-theoryof-plannedbehaviour/(diakses, 12.09.2020). 